\title{
AN EARLY RECORD OF TANDEM RUNNING IN LEPTOTHORACINE ANTS: GOTTFRID ADLERZ, 1896
}

\author{
BY \\ RoBin J. STUART ${ }^{1}$ \\ Department of Zoology, Erindale College, University of Toronto, \\ Mississauga, Ontario, Canada L5L 1C6
}

Tandem running in ants is a recruitment technique in which one ant leads a single follower to a particular target or target area. It has been observed in various subfamilies, including the Myrmicinae, Ponerinae and Formicinae, and appears to function in recruiting nestmates to food discoveries, new nest sites, and into battle. Detailed experimental analyses have revealed that tandem running in some species is mediated by chemical and tactile cues, and various authors have suggested that this recruitment strategy may have been the evolutionary precursor of more sophisticated forms of group and mass recruitment (see Wilson 1971, Hölldobler 1978, Stuart and Alloway 1983).

The term "tandem running" was first used by Wilson (1959) to describe the behaviour of Cardiocondyla venustula and C. emeryi workers as they recruited nestmates to new food sources. However, Wilson $(1959,1971)$ attributed the first observation of tandem running to Hingston (1929), and his description of foraging in Camponotus sericeus. Nonetheless, Gottfrid Adlerz appears to have observed this behaviour even earlier. Adlerz (1896), writing in Swedish, described part of a nest emigration which he observed in nature and which involved a mixed colony of the obligatory slave maker Harpagoxenus (=Tomognathus) sublaevis and its Leptothorax slaves. In translation, Adlerz described the event as follows (see p. 9 of the original text):

"On one occasion, I observed a Tomognathus-Leptothorax community being moved. The move had already started when I arrived. The distance moved was only from one side of the stump

'Present Address: Museum of Comparative Zoology Laboratories, Harvard University, Cambridge MA 02138 U.S.A.

Manuscript received by the editor October 10, 1985. 
to the other and the move was obviously caused by a nearby community of stack ants (Formica rufa) which disturbed the ants at their previous location. During a period of 20 minutes, 8 Tomognathus workers were seen being carried in the usual manner by the Leptothorax workers. In addition, one Tomognathus worker was seen walking at the heels of a Leptothorax worker toward the new nest. The former held its head and antennae on the abdomen of the Leptothorax worker and seemed to get very agitated if it lost its guide during an unexpected turn and did not find it immediately. As is usual during this kind of guidance, the following ant carefully duplicated every little turn made by the guide."

The last few lines of this passage are a fairly accurate description of a tandem run; and the last line indicates that Adlerz was quite familiar with this recruitment technique.

Recent studies of the nest emigration behaviour of various Harpagoxenus species by Stuart and Alloway (1985) tend to confirm Adlerz's observations. Slaves in these mixed colonies are generally responsible for the bulk of the moving effort during nest emigrations: they transport brood and their adult nestmates, and lead tandem runs between the two nests. Slave-maker workers sometimes follow in slave-led tandem runs, and $H$. americanus and $H$. canadensis followers are relatively common. However, Stuart and Alloway did not observe any $\boldsymbol{H}$. sublaevis followers in their study. Nonetheless, $H$. sublaevis followers have been observed in slave-led tandem runs to food (Buschinger and Winter 1977), and they probably occur occasionally during nest emigrations as well.

Various species of nonparasitic leptothoracine ants use tandem runs for recruiting nestmates to food (Möglich et al. 1974), during nest emigrations (Möglich 1978), and for recruitment into battle (Stuart and Alloway 1983); and certain leptothoracine slave makers, including $\boldsymbol{H}$. sublaevis and $\boldsymbol{H}$. canadensis, lead tandem runs during their slave raids (Buschinger et al. 1980, Stuart and Alloway 1983). Other slave makers in this group, including $H$. americanus, leadd processions during their raids (Wesson 1939, Alloway 1979, Buschinger et al. 1980) and these processions constitute one of the more advanced recruitment techniques thought to be evolutionarily derived from tandem running (Wilson 1971, Stuart and Alloway 
1983). $H$. canadensis appears to be an unusual obligatory slave maker, in that it will also lead tandem runs to food and during nest emigrations; behaviours which may be indicative of the relatively primitive nature of this species (Stuart and Alloway 1985).

Thus, Adlerz may have been the first to report tandem running in ants; and the tandem run he described apparently involved a Leptothorax slave leading a Harpagoxenus sublaevis slave maker during a nest emigration.

\section{ACKNOWLEDGMENTS}

The author thanks Vivian Sterne for translating the Adlerz article. Financial support was provided by an Ontario Graduate Scholarship to the author and a Natural Sciences and Engineering Research Council of Canada grant to T. M. Alloway.

\section{REFERENCES}

Alloway, T. M. 1979. Raiding behaviour of two species of slave-making ants, Harpagoxenus americanus (Emery) and Leptothorax duloticus Wesson (Hymenoptera: Formicidae). Anim. Behav. 27: 202-210.

Adlerz, G. 1896. Myrmecologiska studier III. Tomognathus sublaevis Mayr. Bihang Till K. Svenska Vet.-Akad. Handlingar 21 (IV-4): 1-76. (Translation)

BusChINGER, A., AND U. Winter. 1977. Rekrutierung von Nestgenossen mittles Tandemlaufen bei Sklavenraubzugen der dulotischen Ameise Harpagoxenus sublaevis (Nyl.). Ins. Soc. 24: 183-190.

BusChinger, A., W. EHRHARDT AND U. Winter. 1980. The organization of slave raids in dulotic ants-a comparative study (Hymenoptera; Formicidae). Z. Tierpsychol. 53: 245-264.

Hingston, R. W. G. 1929. Instinct and intelligence. Macmillan Company, New York. $\mathrm{xv}+296 \mathrm{pp}$.

HOLlLDOBLer, B. 1978. Ethological aspects of chemical communication in ants. Adv. Study Behav. 8: 75-115.

Möglich, M. 1978. Social organization of nest emigration in Leptothorax (Hymenoptera; Formicidae). Ins. Soc. 25: 205-225.

Móglich, M., U. Maschwitz, and B. Hollddobler. 1974. Tandem calling: A new kind of signal in ant communication. Science 186: 1046-1047.

Stuart, R. J., AND T. M. Alloway. 1983. The slave-making ant, Harpagoxenus canadensis M. R. Smith, and its host-species, Leptothorax muscorum (Nylander): Slave raiding and territoriality. Behaviour 85: 58-90.

Stuart, R. J., AND T. M. Alloway. 1985. Behavioural evolution and domestic degeneration in obligatory slave-making ants (Hymenoptera: Formicidae: Leptothoracini). Anim. Behav. 33: 1080-1088. 
Wesson, L. G. 1939. Contributions to the natural history of Harpagoxenus americanus Emery (Hymenoptera: Formicidae). Trans. Amer. Entomol. Soc. 65: $97-122$.

Wilson, E. O. 1959. Communication by tandem running in the ant genus Cardiocondyla. Psyche 66: 29-34.

WILson, E. O. 1971. The insect societies. Harvard Univ. Press, Cambridge, Mass. $\mathrm{x}+548 \mathrm{pp}$. 

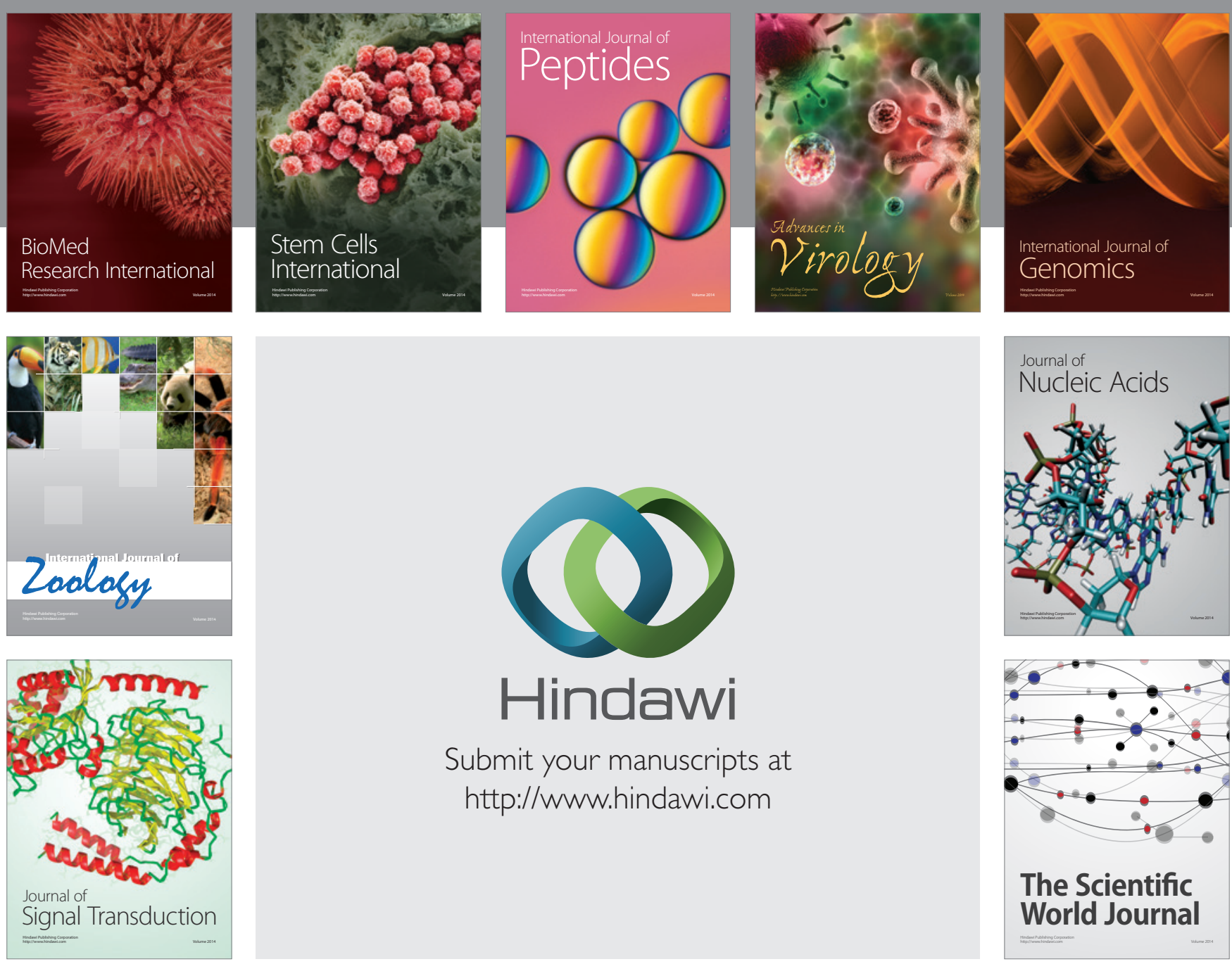

Submit your manuscripts at

http://www.hindawi.com
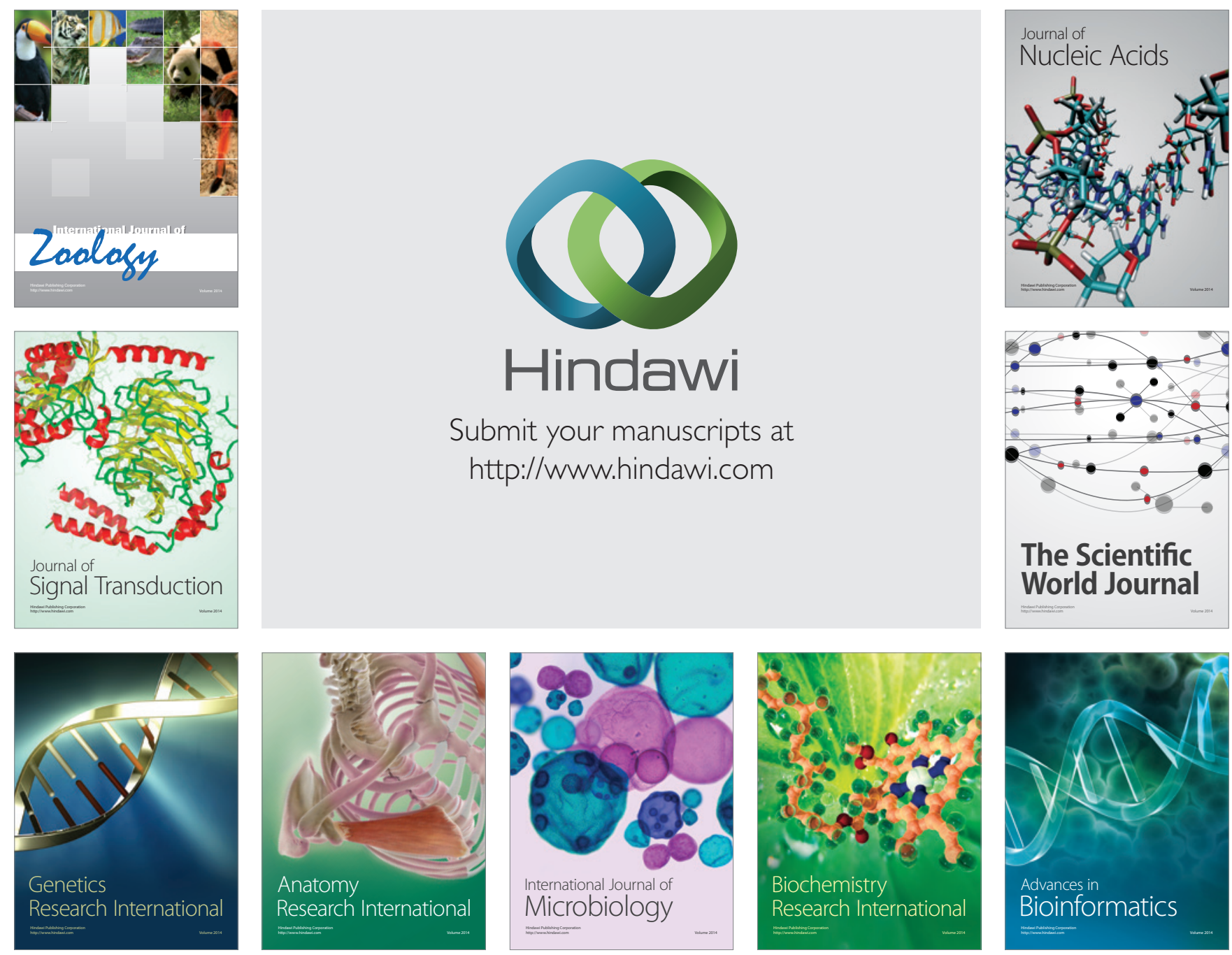

The Scientific World Journal
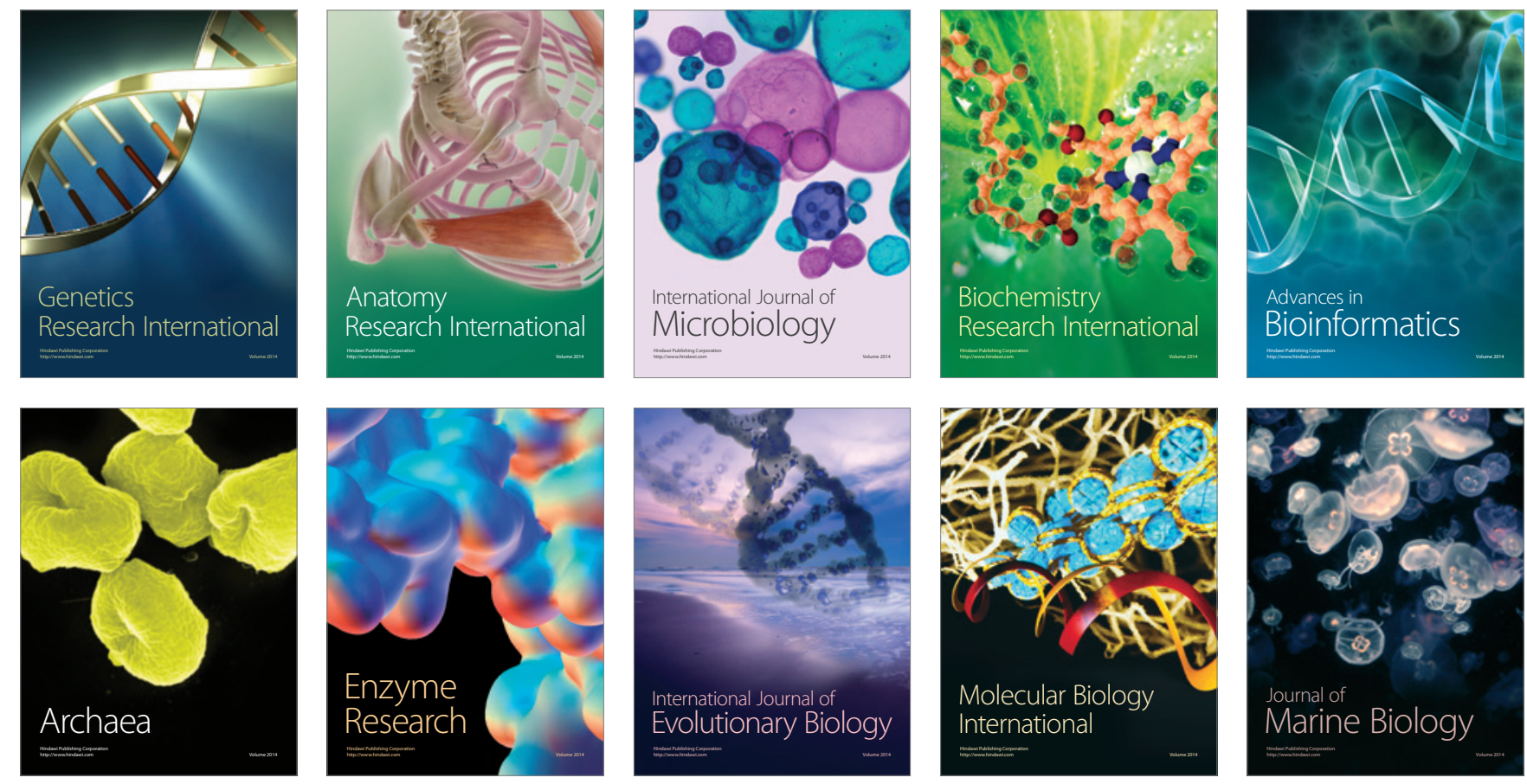